\title{
Ecological Outcomes and Evaluation of Success in Passively Restored Southeastern Depressional Wetlands
}

\author{
Diane De Steven • Rebecca R. Sharitz • \\ Christopher D. Barton
}

Received: 18 March 2010 / Accepted: 31 August 2010/Published online: 24 November 2010

(C) Society of Wetland Scientists (Outside the USA) 2010

\begin{abstract}
Depressional wetlands may be restored passively by disrupting prior drainage to recover original hydrology and relying on natural revegetation. Restored hydrology selects for wetland vegetation; however, depression geomorphology constrains the achievable hydroperiod, and plant communities are influenced by hydroperiod and available species pools. Such constraints can complicate assessments of restoration success. Sixteen drained depressions in South Carolina, USA, were restored experimentally by forest clearing and ditch plugging for potential crediting to a mitigation bank. Depressions were assigned to alternate revegetation methods representing desired targets of herbaceous and wet-forest communities. After five years, restoration progress and revegetation methods were evaluated. Restored hydroperiods differed among wetlands, but all sites developed diverse vegetation of native wetland species. Vegetation traits were influenced by hydroperiod and the effects of early drought, rather than by revegetation method. For mitigation banking, individual wetlands were assessed for improvement from pre-restoration condition and similarity to assigned reference type. Most wetlands met goals to increase hydroperiod, herb-species dominance, and wetland-plant composition. Fewer wetlands achieved
\end{abstract}

D. De Steven $(\bowtie)$

U.S. Forest Service Southern Research Station,

Center for Bottomland Hardwoods Research,

P. O. Box 227, Stoneville, MS 38776, USA

e-mail: ddesteven@fs.fed.us

R. R. Sharitz

Savannah River Ecology Laboratory, University of Georgia,

Aiken, SC 29802, USA

C. D. Barton

Department of Forestry, University of Kentucky,

Lexington, KY 40546, USA equivalence to reference types because some vegetation targets were incompatible with depression hydroperiods and improbable without intensive management. The results illustrated a paradox in judging success when vegetation goals may be unsuited to system constraints.

Keywords Carolina bay · Mitigation bank · Vegetation dynamics $\cdot$ Wetland restoration

\section{Introduction}

Many depressional wetlands are restored by passive methods that focus on repairing altered hydrology (typically by disrupting artificial drainage) and allowing wetland plants to recolonize naturally from seed banks and dispersal. This approach can re-establish wetland vegetation through species filtering and selection by the restored hydrologic regime (van der Valk 1981; "self-design" of Mitsch and Wilson 1996). A possible shortcoming is that passively restored sites may lack characteristic plant species or guilds that are absent in seed banks or dispersal-limited (Galatowitsch and van der Valk 1996b; Seabloom and van der Valk 2003; De Steven et al. 2006); the reasons may include site disturbance history, adjacent land use, or distance from source habitats (Zedler 2000; Aronson and Galatowitsch 2008). Recovering the absent floristic elements may take more time or require more costly active reintroductions. Despite some limitations, passive restoration has been advocated where possible, because natural processes have greater potential to achieve selfsustaining, low-maintenance systems (e.g., Mitsch et al. 1998; Halle 2007; see also NRC 2001).

A persistent topic in the ecological restoration literature concerns how to define realistic goals and appropriate 
standards for success (e.g., Ehrenfeld 2000; Kentula 2000; Hobbs 2007; Matthews and Endress 2008). If passive restoration methods are used, what are ecologically sound expectations? Resemblance to natural reference sites is a desired standard; however, by what criteria and to what level of similarity are often undefined (Reiss et al. 2009). If wetlands are not deliberately planted, criteria based strictly on plant taxonomic similarity may be too narrow compared to more functional criteria (NRC 2001). Failure to recover natural hydrology, or establishing a "restored" vegetation dominated by non-native invasives, are clearly undesirable outcomes (e.g., Galatowitsch and van der Valk 1996a; Mulhouse and Galatowitsch 2003). Conversely, if intrinsic hydroperiod capacity and a diverse native wetland flora were re-established, a passively restored wetland could attain good structural and functional condition without closely matching a specific reference plant composition. Whether such an outcome constitutes success or failure is less obvious. The answer may depend partly on restoration context, but also on recognizing ecological constraints in relation to stated goals (Ehrenfeld 2000; Thom 2000). For example, if restored hydroperiod is not predictable, a desired vegetation type could be incompatible with a wetland's hydrologic capacity to support it. The issue is especially pertinent to depressional wetlands, whose plant communities are structured by seasonal hydroperiods that differ inherently with depression geomorphology and other factors (Kirkman et al. 2000; De Steven and Toner 2004; Casey and Ewel 2006).

Restoration of drained depressional wetlands has received only limited study in the Southeast U.S. Coastal Plain (Singer 2001; Szuch et al. 2006). Beginning in 2000, the potential outcomes of passive restoration were tested in a six-year project at the U. S. Department of Energy's Savannah River Site (SRS), South Carolina. The project was a replicated experiment using 16 degraded depressional wetlands with a past history of drainage and agricultural impacts (Barton et al. 2004). The depressions were draining by surface outflow ditches, but had developed a successional forest cover after being abandoned from active uses for several decades. All sites were restored experimentally by: 1) removing the forest cover, 2) plugging ditches to increase water retention and hydroperiod, and 3) allowing for revegetation from seed banks and dispersal. Initial results indicated that, within three years, all sites established high coverage of native perennials and mudflat annuals that emerged from diverse seed banks (De Steven et al. 2006). Wetland species (OBL and FACW; Reed 1997) comprised a majority of the plant cover, restored sites had many species in common with natural reference wetlands, and non-native species were negligible.

The project's experimental design had additional elements to address various research questions (see Barton et al. 2004), including an interest by SRS land managers to determine if simple methods could establish specific wetland vegetation types in association with upland forest management. Accordingly, the 16 wetlands had been assigned randomly to approaches for achieving either of two "target" vegetation types (herbaceous or wet forest), and to alternative systems for managing upland forest buffers (unmanaged, or thinned and periodically burned). The targets and management options were based partly on state-change models for plant community types (aquatic, herbaceous, and forested) in Southeast depressional wetlands (Kirkman 1995; De Steven and Toner 2004). Of particular interest was whether hydrology restoration and forest removal alone could supply conditions favorable to establishing the herbaceous vegetation type.

The project was unusual as an ecological experiment that was also associated with development of a single-user mitigation bank for the SRS. The depression restorations were not compensatory for specific permitted losses; rather, they would enter a bank of restored wetlands to supply future in-kind offsetting (as needed) of unavoidable wetland impacts on the SRS (US-DOE 1997; Barton and Singer 2001). After five years, each wetland would be evaluated as restored or enhanced based on success criteria in a plan overseen by a multi-agency Mitigation Banking Review Team (NRC 2001 describes the MBRT process). Initial success criteria were to develop longer hydroperiods and greater representation of wetland (OBL and FACW) plant species compared to pre-restoration conditions (US-DOE 1997), but the plan eventually added the vegetation targets that had been assigned experimentally to individual depressions (Osteen 2003). Thus, questions of restoration success required assessing both net improvement and resemblance to the intended vegetation types.

Early results had indicated that passive restoration could establish diverse native wetland vegetation (De Steven et al. 2006). In this paper, we synthesize the final findings after five years in relation to two questions: 1) what were the ecological outcomes of methods to restore the desired vegetation types? and 2) did restored wetlands meet the project criteria for restoration success? The results illustrated how constraints on restoring specific plant communities could be understood from knowledge of natural wetland dynamics, and how such constraints might affect the evaluation of restored wetlands in a mitigation-bank context.

\section{Methods}

Study Area

The U. S. Department of Energy's Savannah River Site (SRS) is an $800-\mathrm{km}^{2}$ National Environmental Research 
Park located on South Carolina's Upper Coastal Plain. Most of the SRS consists of managed and natural pine and hardwood forests that contain numerous depressional wetlands ranging in size from $<1$ to 50 ha (Kilgo and Blake 2005). Prior to the 1950s, the landscape was mostly in agriculture, with many depressional wetlands altered by ditching and drainage. Agricultural land use ended when the SRS was established in 1951, and the farmed uplands were reforested to southern pines. Altered wetland depressions reverted by natural succession to various vegetation types, depending upon the extent to which remnant ditches ceased to drain and ponding regimes recovered (Kirkman et al. 1996).

The regional climate is humid subtropical, with mean annual rainfall of $1,200 \mathrm{~mm}$, a long growing season, and periodic multi-year droughts. During the study years (2000-2005), a period of below-normal rainfall starting in 1999 led to drought conditions through 2002; this was followed by very high rainfall in 2003 and a return to average rainfalls thereafter (Fig. 1). In this regional climate, depressional wetlands exhibit seasonal ponding, with high water levels in early spring that fall at varying rates during the growing season. Annual hydroperiods (ponding durations) differ intrinsically among wetlands and also between years, becoming progressively shorter during
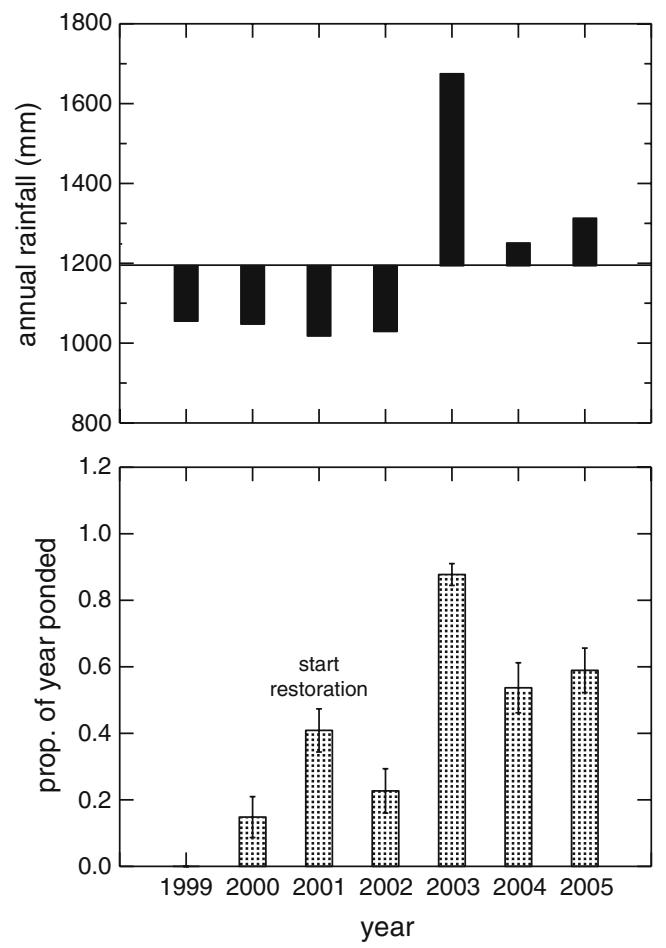

Fig. 1 Annual rainfall and annual hydroperiods (mean \pm SE) for 16 experimental wetlands. Rainfall is from SRS recording stations, shown relative to the 30 -year normal at a nearby weather station in Blackville, SC. Hydroperiods differed significantly across years $(F=76.9 ; \mathrm{df}=5,60 ; P<0.001)$ droughts (Mulhouse et al. 2005; Stroh et al. 2008). What controls the inherent hydroperiod capacity of individual depressions is not fully understood, but likely factors include basin geomorphology, topographic position, and soil type (De Steven and Toner 2004).

\section{Restoration Project Design}

Project details have been described previously (Barton et al. 2004; De Steven et al. 2006). The 16 experimental depressions were small $(0.5-2 \mathrm{ha})$ and distributed widely across the SRS. Soils were classed as loamy to clayey Arenic or Typic Ochraquults; these are hydric soil types, but some sites showed non-hydric features related to drainage disturbance (Barton et al. 2008). The depressions were forested with vegetation that was hydrophytic (meeting wetland jurisdictional criteria; ACOE 1987) but dominated by facultative (FAC) tree species indicative of prior drainage (e.g., sweetgum, Liquidambar styraciflua; loblolly pine, Pinus taeda; water oak, Quercus nigra). Disturbed depressions with this forest composition are often shorthydroperiod basins with ponding (if any) mainly in the dormant season (De Steven and Toner 2004). The study sites were still draining from surface ditches when the study began (Barton et al. 2008).

Experimental restoration consisted of complete forest removal and plugging ditches at the basin rims with impermeable clays. In all depressions but one, forest harvest was completed by early 2001 when the sites were still dry. Ditches were plugged late in that year, but owing to drought conditions there were minimal to no water outflows during the interim (Barton et al. 2008). One site was harvested and plugged in early 2002 . The post-harvest starting condition in all depressions was exposed soils with scattered woody debris and tree stumps. A foliar herbicide (Garlon $\left.{ }^{\circledR} 4\right)$ was applied to resprouting trees in summer 2001 but not continued thereafter.

The wetlands had been assigned in a randomized $2 \times 2$ factorial design to alternative revegetation methods and upland-buffer management systems (4 wetlands per treatment combination). Revegetation method was either: 1) passive from seed banks and dispersal, for a desired target vegetation of "herbaceous (herb-dominated) wetland", or 2) passive but supplemented with low-density plantings of wetland tree seedlings (baldcypress, Taxodium distichum, and swamp tupelo, Nyssa biflora), for a longer-term desired target of "wet forest". It was hypothesized that the "passive-only" method might promote herbaceous wetland if no new trees were planted after harvest and if restored water levels suppressed woody regrowth. In "passive-supplemented" wetlands, tree seedlings were planted at wide spacing ( $\geq 5 \mathrm{~m}$ apart) just after site harvest. Surrounding upland buffers were planned as either unmanaged pine-hardwood forest 
or thinned pine forest with periodic fire. Buffer thinning was simultaneous with harvest of the depression interiors. A post-harvest burn planned for 2001 was prevented by drought conditions that imposed SRS-wide burning restrictions; six of eight pine buffers were burned early in 2003 when drought ended, but the fires spread into only one wetland that was dry at the time of burning and so had little influence on wetland vegetation.

\section{Sampling Methods and Data Analysis}

Water levels were monitored continuously starting before restoration (2000, year 0) (Barton et al. 2008). We focused on hydroperiod as a key indicator of depression hydrologic regime. Hydroperiods for each wetland were calculated as the proportion (percent) of days ponded at depth $>0$ for each year (annual) and growing season (Apr 1-Nov 1) through 2005. Hydroperiods of six unmanipulated wetland depressions (herbaceous and forested) across the SRS were monitored simultaneously as controls for detecting change in the experimental wetlands (Barton et al. 2008).

Vegetation was sampled before restoration and for five years after (2001-2005, years 1-5) at permanent sample points placed systematically along transects in each wetland (De Steven et al. 2006). In year 0, cover classes of woody species $>1 \mathrm{~m}$ tall (tree, sapling, and shrub strata inclusive) were estimated in three to five 0.10 -ha plots, augmented with cover-class estimates for ground-layer species (woody seedlings and all herbs) in twelve $4-\mathrm{m}^{2}$ quadrats. After restoration, species cover classes were estimated annually in eight $4-\mathrm{m}^{2}$ quadrats, and the larger 0.10 -ha plots were re-sampled in the final year to re-estimate taller woody cover. Cover classes (Daubenmire scale; Peet et al. 1998) were converted to percent covers using the midpoints of the scale ranges and averaged within each wetland. Planted tree seedlings were censused yearly for survival and height (Sharitz et al. 2006).

We described vegetation composition with commonly used plant-guild metrics based on life-history form (aquatics, annual and perennial herbs, woody plants) and wetland indicator category (Reed 1997), with OBL and FACW categories grouped as true "wetland" species. Metrics included total species richness, relative proportions of herbaceous species and wetland species, relative proportional covers of herbaceous and wetland species, and numbers and percent covers of life-history forms. To synthesize with prior findings (De Steven et al. 2006), we focus here on data for three years: year 0 (before restoration), and years 1 and 5 (initial and final response). For the wetland restored in 2002, the 2002 data could represent "year 1" because 2001 and 2002 were both drought years that resulted in comparable first-year responses. Highly flooded conditions in year 3 had the effect of "re-setting" vegetation development in all wetlands, so year 5 metrics were also comparable for all wetlands.

Temporal changes (comparing pre- and post- restoration metrics) and the effects of experimental treatments were tested by repeated-measures ANOVA, with revegetation method and upland management as between-wetland factors and year as the within-wetland repeated measure. Proportional and percent cover metrics were transformed (arcsine square root and log transformations, respectively). Neither tree planting nor buffer-zone management treatment had any significant statistical effect on any metric (indicating similar vegetation development in all 16 wetlands), so for simplicity we show results only for between-year differences. Among individual wetlands, relationships between fifth-year plant metrics and final restored hydroperiod were tested by Spearman rank correlations, where restored hydroperiod was calculated as the mean annual hydroperiod in years 4 and 5 when rainfalls were normal. Two-sample $t$-tests were used to test whether wetland size (area) or soil type (a three-category variable for soil series) differed between wetlands with above-average versus below-average restored hydroperiods. SYSTAT ${ }^{\circledR}$ software was used for the analyses.

We estimated similarity in floristic (species) composition between restored and natural wetlands (described below) using the Sorenson measure on presence-absence data (Jongman et al. 1995). Similarity measures often have low values because of sensitivity to stochastic occurrences of infrequent or transient species. More robust estimates were obtained by combining some highly similar species at the generic level and by omitting species seen only once (across all wetlands) at low abundance. Equivalence of floristic composition between wetland groups was tested with MRPP (multiple response permutation procedures) (McCune and Grace 2002). Plant species nomenclature is based on Godfrey and Wooten (1981).

\section{Assessing Restoration Success}

Incorporating the experimental design into the mitigation plan required that each wetland be assessed individually for these success criteria in year 5 (Osteen 2003): 1) increased water level/ponding duration and wetland-plant composition ("net improvement"), 2) hydroperiod and plant composition "comparable" to the target reference type (herbaceous or wet-forest), and 3) for wet-forest restorations, at least $50 \%$ survival of planted tree seedlings. The first criterion was testable statistically for wetlands as a group, but there was no clear way to define a "significant" increase for a single wetland. The second criterion was narrative, with no specified measures or degree of similarity to reference. For these two criteria, we used typical hydrology metrics (annual- and growing-season hydroperiod) and vegetation 
metrics (species richness, relative percentage herbaceous species and wetland species, and relative proportional abundances of herbaceous and wetland species) as indicators of important functional and compositional traits to be expected in reference communities.

Estimating net improvement required different approaches for hydrology and vegetation. For restored hydroperiod, substantial improvement was indicated if the net increase between year 0 and year 5 was more than the average net increase in the simultaneously monitored unmanipulated wetlands (similar to "before-after, controlimpact" analysis; see Underwood 1994); this accounted for the problem that even natural wetlands were dry during the pre-restoration year. For plant metrics, there was no meaningful control group for individual change from a pre-restoration forest that was removed and replaced with rapidly aggrading successional vegetation. Conservatively, we scored whether a metric had increased by at least $50 \%$ as a percentage of the pre-restoration value, which was more stringent than crediting any small difference greater than zero as meaningful.

Resemblance to a reference type is best determined from datasets that describe the range of natural variation among natural wetlands (White and Walker 1997; Kentula 2000; NRC 2001). We compared restored sites to their assigned wetland type based on datasets for 20 herb-dominated wetlands and 9 wet-forest (cypress-tupelo) wetlands from a comprehensive regional study of depression vegetation (De Steven and Toner 2004) and a related nine-year hydrologic study (R. Lide, unpublished data). We obtained typical ranges of metric values for the two types of reference wetlands, which differed in some metrics but not others (Table 1). Herbaceous wetlands generally have longer hydroperiods and greater representation of herb species, whereas both types have similar average species richness and representation of wetland species. Metric values for a restored wetland had to reach or exceed the minima of these ranges to be comparable to reference (see Kentula 2000; Kolka et al. 2000); the number of wetlands doing so was tabulated for each target vegetation type. All metrics were appropriate to assess the herbaceous-wetland restorations, which could feasibly resemble herbaceous reference communities within five years. The herb-species metrics were less relevant for wet-forest restorations because of young successional age; for example, relative herb cover after five years would inevitably be higher (and relative woody cover, lower) compared to mature forests with full canopy cover.

The mitigation plan did not specify soil parameters as success criteria, given that successful wetland hydrology will promote hydric soil traits over the long term. Soils of the experimental wetlands were intact and generally met hydric criteria before restoration (Barton et al. 2008), which qualified them as "existing and suitable" for restoration and mitigation-bank crediting (US-DOE 1997).

\section{Results}

Responses to Experimental Restoration

Recovery of hydroperiod potential was slowed by drought (Fig. 1; see Barton et al. 2008). Before restoration, most wetlands held water for $<15 \%$ of the year, although a few were initially wetter (hydroperiods $>30 \%$ ). In 2001 transient summer rains temporarily lengthened first-year hydroperiods, but wetlands dried later that year and remained mostly dry through 2002. Very high rainfall in year 3 (2003) inundated all sites, resulting in unusually prolonged ponding and maximum water depths averaging $0.8 \mathrm{~m}$ (range 0.6-1.2 m). "Typical" restored hydroperiods under normal rainfall conditions were achieved in years 4 and 5 and averaged $56 \%$; however, a wide range (18-100\%) around that average showed that individual depressions differed intrinsically in hydrology. Roughly one-third each of wetlands ponded for $<40 \%, 40-70 \%$, and $>70 \%$ of the year. Wetter versus drier wetlands did not differ significantly in either size or soil type $(t=0.04$ and $0.97, \mathrm{df}=14, P>0.10)$. All restored hydroperiods met jurisdictional-wetland standards (ACOE 1987; Barton et al. 2007).
Table 1 Range of typical values for hydroperiod and plant composition metrics in natural reference wetlands. Data are from 20 herbaceous wetlands and 9 wet-forest (cypress-tupelo) wetlands (see Methods)

\begin{tabular}{lcc}
\hline Metric & \multicolumn{2}{l}{ Typical reference values (range) } \\
\cline { 2 - 3 } & Herbaceous wetland & Wet forest \\
\hline Annual hydroperiod (\% of year) & $50-100$ & $30-100$ \\
Growing-season hydroperiod (\% of year) & $40-100$ & $30-100$ \\
Species richness (number of species) & $10-33$ & $7-33$ \\
Percent herb species & $60-95$ & $0-75$ \\
Percent wetland species & $60-95$ & $60-80$ \\
Relative abundance of herb species (\%) & $60-99$ & $0-50$ \\
Relative abundance of wetland species (\%) & $60-98$ & $60-90$ \\
\hline
\end{tabular}


Revegetation method did not affect any vegetation metric (see Methods), essentially because the small planted tree seedlings were widely spaced and did not suppress the short-term development of surrounding vegetation. Consequently, planted and unplanted wetlands did not differ in species composition (MRPP test, $T=-0.1$, n.s.). Irrespective of planting, all key vegetation metrics changed significantly over time and all wetlands showed similar trends (Table 2). Total plant cover in the multi-strata pre-restoration forest averaged 141\%; after restoration, plant cover reached $77 \%$ in year 1 and $102 \%$ by year 5 . Average species richness increased from 23 species before restoration to 43 and 35 species in years 1 and 5 , respectively. Herbaceous plants were a minor component before restoration, but increased to $>60 \%$ of species and of relative cover, on average. Wetland species (OBL and FACW) averaged $<45 \%$ of species and of relative cover before restoration, but increased to averages of $50 \%$ in year 1 and $>60 \%$ by year 5. Large ranges in values (Table 2) indicated that individual wetlands differed widely in some vegetation traits. By year 5 , both proportion and relative cover of wetland species were greater in wetlands with longer hydroperiods (Spearman $r=0.81$ and 0.71 , respectively, $\mathrm{df}=14$, both $P<0.01$ ).

Numbers and percent covers of all plant life-history forms also differed significantly across years (ANOVAs, $\mathrm{df}=2$, 24, all $P<0.01$ ) (Fig. 2). Post-restoration, perennials were the dominant herbs and increased from $42 \%$ to $53 \%$ mean cover between years 1 and 5 . Annual species emerged after initial site preparations but declined in presence and cover after year 1. Aquatic plants, absent before restoration, maintained a small presence in wetter restored sites. Forest harvest removed virtually all pre-restoration woody cover, but woody species persisted by resprouting or colonizing from seed. Mean woody-plant cover increased from $18 \%$ to $40 \%$ between years 1 and 5 (Fig. 2). Within this category, woody vines maintained $12-15 \%$ average cover, whereas mean tree and shrub cover increased from $5 \%$ to $25 \%$ due to resprouting in some wetlands. Differences in degree of woody resprouting contributed to among-wetland variation in relative herbaceous/woody cover. By year 5, it appeared that higher woody cover was associated with shorter restored hydroperiod (Spearman $r=-0.50, \mathrm{df}=14$, $P=0.05$ ).

Table 2 Mean values (range in parentheses) for vegetation metrics before and in the first and fifth years after restoration for $n=16$ wetlands

ANOVA $\mathrm{F}$ is for difference among years, where $\mathrm{df}=2,24, *$ $P<0.05, * * P<0.01$
Nearly 240 species occurred among all restored wetlands, of which $95 \%$ were native species and $80 \%$ were herbaceous species. Of the few non-natives, most were facultative or upland species that emerged during the drought but disappeared after rewetting. The restored flora (Table 3) was characterized by species-rich genera of wetland sedges and rushes (Cyperus, Eleocharis, Juncus, Rhynchospora), facultative witch-grasses (Dichanthelium), and diverse wetland forbs including meadow-beauties (Rhexia), seed-boxes (Ludwigia), and water-smartweed (Polygonum hydropiperoides). With the exception of Cyperus, these common taxa are typical of reference vegetation (Table 3 ). In contrast, several clonal perennial dominants of natural herbaceous wetlands (maidencane, Panicum hemitomon; southern cutgrass, Leersia hexandra; peatland sedge, Carex striata) were infrequent or absent. Among woody plants, increases in cover were evident for resprouting tree species such as sweetgum (Liquidambar styraciflua), red maple (Acer rubrum), and oaks (Quercus spp.), and for loblolly pine (Pinus taeda) colonizing as new seedlings. Woody vines were also common. Of the two planted tree taxa, cypress (Taxodium spp.) did not recruit naturally into restored sites; swamp tupelo (Nyssa biflora) recruited in some wetlands where it had been present before restoration.

Sampled species richness in restored wetlands (Table 2) and reference wetlands (Table 1) was similar. The collective flora of restored sites had $58 \%$ and $53 \%$ of taxa, respectively, in common with herbaceous and wet-forest reference communities; notably, the two reference types have $67 \%$ of their taxa in common with each other (e.g., see Table 3). Individual restored sites averaged $37 \%$ and $41 \%$ similarity, respectively, to herbaceous and wet-forest floras. These values were comparable to mean similarities of $36 \%$ among herbaceous reference sites and $41 \%$ among wet-forest reference sites.

\section{Restoration Assessment}

Based on net-improvement criteria, hydroperiod increased over pre-restoration values in six planned wet-forest sites and in all eight planned herbaceous-vegetation sites (Table 4). Substantial increases for all vegetation metrics

\begin{tabular}{lcccc}
\hline Metric & Pre-Restoration & Year 1 & Year 5 & ANOVA F \\
\hline Number of species & $23(9-36)$ & $43(18-63)$ & $35(14-57)$ & $17.9^{* *}$ \\
Percent herb species & $20(0-47)$ & $69(50-80)$ & $66(50-80)$ & $69.5^{* *}$ \\
Percent wetland species & $33(16-58)$ & $51(36-71)$ & $61(35-86)$ & $64.7^{* *}$ \\
Total plant cover (\%) & $141(59-227)$ & $77(26-151)$ & $102(53-191)$ & $13.9^{* *}$ \\
Herb species relative cover & $7(0-35)$ & $76(52-97)$ & $63(30-96)$ & $64.4^{* *}$ \\
Wetland species relative cover & $42(5-80)$ & $50(15-94)$ & $62(14-96)$ & $4.6^{*}$ \\
\hline
\end{tabular}




\section{DE- AI09-00SR22188 JOURNAL ARTICLE $2010 \quad 10-12-P$}

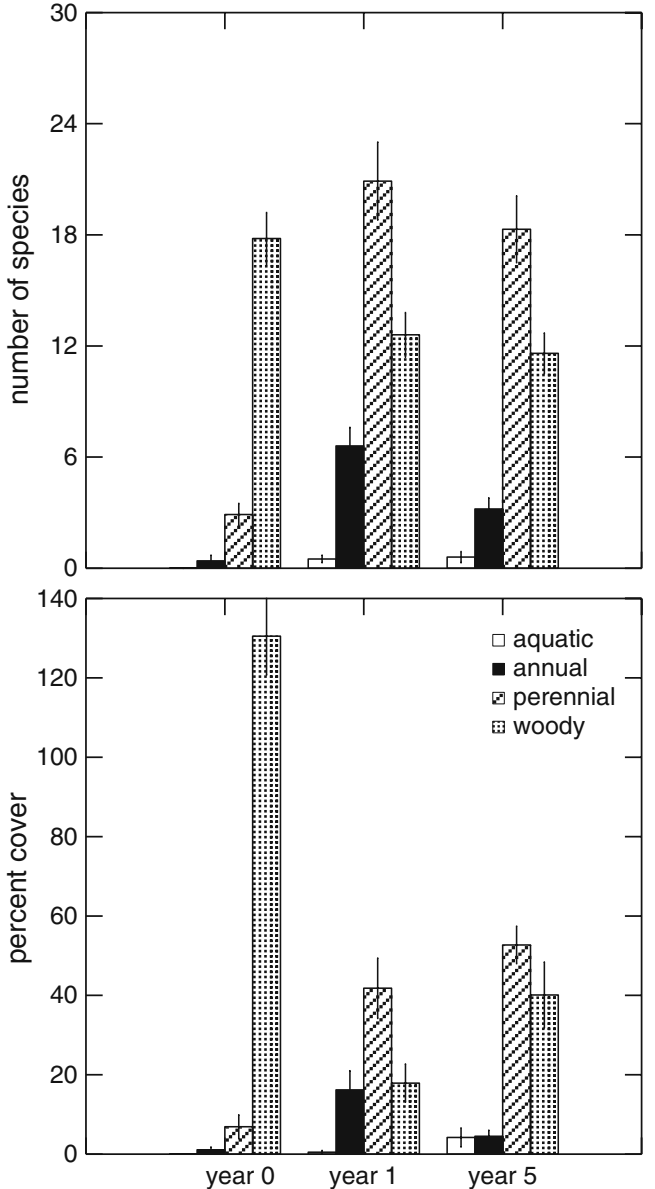

Fig. 2 Number of species and percent cover of plant life-history forms (aquatic plants, annual herbs, perennial herbs, woody plants) before restoration (year 0, 2000) and in years 1 (2001) and 5 (2005) after restoration. Data are means \pm SE for 16 wetlands

occurred in six wet-forest sites and seven herbaceouswetland sites. Thus, irrespective of the target vegetation, 13 of 16 depressions fully satisfied the original goals of longer hydroperiods and more diverse vegetation communities dominated by wetland species (Table 4). Three depressions exhibited fewer net changes but were enhanced by forest removal (allowing more herbaceous plants) and by additions of planted cypress and swamp tupelo.

In contrast to the net-improvement results, only eight wetlands (five wet-forest and three herbaceous-wetland sites) met all criteria relative to their assigned target vegetation type when compared to reference data (Table 4). Hydroperiod and relative cover metrics were particularly diagnostic. Hydroperiods comparable to the target wetland type were displayed by six wet-forest sites, but only three herbaceous-wetland sites. Five wet-forest sites, met the criterion for $\geq 60 \%$ relative cover of wetland species, whereas only three herbaceous-wetland sites met the required criteria for $\geq 60 \%$ relative herbaceous cover and $\geq 60 \%$ wetland-species cover. Planned herbaceous wetlands failing to meet the criteria generally did so because shorter restored hydroperiods allowed for greater persistence of woody species and facultative herb species compared to the wetter reference sites (MRPP test, $T=-8.5, P<0.01$ ). Conversely, four of the five successful wet-forest sites were so wet (hydroperiods $>70 \%$ ) that their vegetation also met relative cover criteria for herbaceous wetland. All wet-forest sites differed floristically from mature reference forests in having a greater presence and variety of herbaceous species (MRPP test, $T=-4.7, P<0.01)$.

For wet-forest restorations, the mitigation plan had not indicated whether the two planted tree species had to meet the survival criterion ( $\geq 50 \%$ by year 5 ) individually or collectively. All eight wet-forest restoration sites had $>50 \%$ survival of planted cypress seedlings (see Sharitz et al. 2006). Swamp tupelo seedlings survived poorly $(<30 \%)$ in most sites, likely owing to drought stress and competition. Surviving seedlings attained heights averaging 1.9 and $1.2 \mathrm{~m}$ for cypress and tupelo, respectively. Planted trees began to be detected in the plant cover by the fifth year, averaging comparable cover $(5 \%)$ to that of other tree species (Table 3).

\section{Discussion}

\section{Ecological Outcomes of Passive Restoration}

In these small Coastal Plain depressions, passive restoration methods established natural hydroperiods and diverse native wetland vegetation. Ditch plugging returned ponding depths and durations to levels reflecting each basin's capacity (Barton et al. 2008; see also Taylor and DeBiase 2005). Seed banks were dominated by native herbaceous wetland species (De Steven et al. 2006). As a group, restored sites had equivalent plant species richness and similar species composition to reference vegetation, and non-native species were negligible. Some wetlands developed an herbaceous community; others will develop eventually to a forest of planted wetland trees and naturally colonizing woody species (wetland and facultative). Restored wetlands diverged from reference communities mainly in two ways: 1) a typical guild of clonal perennial species did not colonize naturally, and 2) the specified target vegetation was not always achieved.

Southeastern herbaceous depressions are often dominated by native clonal graminoids such as maidencane and southern cutgrass that develop a perennial cover matrix (Kirkman 1995; De Steven and Toner 2004). These clonal dominants are dispersal-limited and were not found in the seed banks and pre-restoration vegetation of most experimental wetlands, except in a few sites with remnant populations (De Steven et al. 2006). However, the functional 
Table 3 Average abundance of common taxa in years 1 and 5. Occurrence in herbaceous/forested reference wetlands is noted

\begin{tabular}{|c|c|c|c|c|c|}
\hline \multirow[t]{2}{*}{ Taxon name } & \multirow[t]{2}{*}{ Indicator group $^{\mathrm{a}}$} & \multirow[t]{2}{*}{ Life form } & \multicolumn{2}{|c|}{ Mean $\%$ cover } & \multirow{2}{*}{$\begin{array}{l}\text { Frequency in reference } \\
\text { (herbaceous/forest) }\end{array}$} \\
\hline & & & Year 1 & Year 5 & \\
\hline \multicolumn{6}{|l|}{ Herbaceous Taxa } \\
\hline Cyperus (7 spp.) & wetland & $\mathrm{rush} / \mathrm{sedge}^{\mathrm{c}}$ & 11 & + & \\
\hline Eleocharis (7 spp.) & wetland & $\mathrm{rush} / \mathrm{sedge}^{\mathrm{c}}$ & 4 & 5 & $\mathrm{C} / \mathrm{C}$ \\
\hline Juncus (11 spp.) & wetland & $\mathrm{rush} / \mathrm{sedge}^{\mathrm{c}}$ & 1 & 3 & $\mathrm{C} / \mathrm{C}$ \\
\hline Rhynchospora (11 spp.) & wetland & rush/sedge & 3 & 4 & $\mathrm{f} / \mathrm{f}$ \\
\hline Scirpus cyperinus & wetland & rush/sedge & 1 & 4 & $f / f$ \\
\hline Erianthus sp. & wetland & grass & - & 3 & $\mathrm{C} / \mathrm{f}$ \\
\hline Panicum verrucosum & wetland & $\operatorname{grass}^{\mathrm{c}}$ & 17 & 5 & $/ \mathrm{f}$ \\
\hline Hypericum gymnanthum & wetland & forb & + & - & \\
\hline Ludwigia (11 spp.) & wetland & forb $^{c}$ & 2 & 4 & $\mathrm{C} /$ \\
\hline Polygonum hydropiperoides & wetland & forb & - & 8 & $\mathrm{C} / \mathrm{f}$ \\
\hline Rhexia (mariana, virginica) & wetland & forb & 1 & 2 & $f / f$ \\
\hline Rotala ramosior & wetland & forb $^{c}$ & + & - & \\
\hline Carex albolutescens & facultative & rush/sedge & 14 & 3 & \\
\hline Dichanthelium (9 spp.) & facultative & grass & 5 & 10 & f/ \\
\hline Andropogon virginicus & facultative & grass & + & 2 & \\
\hline Erechtites hieracifolia & facultative & forb $^{c}$ & 2 & + & \\
\hline Eupatorium capillifolium & upland & forb & 1 & 6 & \\
\hline Polypremum procumbens & upland & forb & 2 & + & \\
\hline \multicolumn{6}{|l|}{ Woody Taxa } \\
\hline Acer rubrum & wetland $^{\mathrm{b}}$ & tree & + & 4 & $\mathrm{f} / \mathrm{C}$ \\
\hline Quercus (laurifolia, phellos) & wetland & tree & + & 7 & $/ \mathrm{f}$ \\
\hline Trachelospermum difforme & wetland & vine & 4 & 4 & \\
\hline Nyssa (biflora, sylvatica) & wetl, facult & tree & - & 3 & $\mathrm{C} / \mathrm{C}$ \\
\hline Diospyros virginiana & facultative & tree & + & 2 & $\mathrm{f} / \mathrm{C}$ \\
\hline Liquidambar styraciflua & facultative & tree & 2 & 7 & $\mathrm{C} / \mathrm{C}$ \\
\hline Pinus taeda & facultative & tree & + & 4 & $\mathrm{C} / \mathrm{C}$ \\
\hline Quercus nigra & facultative & tree & + & 4 & \\
\hline Ampelopsis arborea & facultative & vine & - & 7 & \\
\hline Campsis radicans & facultative & vine & 9 & 11 & $/ \mathrm{f}$ \\
\hline Smilax (3 spp.) & facultative & vine & 3 & 3 & $\mathrm{f} / \mathrm{C}$ \\
\hline Rhus copallina & upland & shrub & + & - & \\
\hline Rubus sp. & upland & shrub & 1 & + & \\
\hline
\end{tabular}

${ }^{\mathrm{a}}$ where wetland $=$ OBL, FACW; facultative $=$ FAC; upland $=$ FACU, UPL (Reed 1997)

${ }^{\mathrm{b}}$ for the Coastal Plain subspecies; facultative elsewhere in the geographic range

"+" indicates $<1 \%$ mean cover, and "-"indicates that the species was uncommon in that year

Herb taxa are perennial, unless noted by ${ }^{\mathrm{c}}$ (annual or taxon includes annuals)

${ }^{\mathrm{d}}$ where $\mathrm{C}=$ common (in $\geq 50 \%$ of sites) and $\mathrm{f}=$ frequent (in $25-50 \%$ of sites)

importance of this outcome is uncertain. Absence of a dominant emergent species can change vegetation structure substantially, but the result may be a wetland that has different function but no less value ecologically. The original vegetation that existed prior to the historic drainage disturbance is unknown. In a given site, the clonal species could have been lost after drainage or may never have been present. In either case, establishing these dispersal-limited species in restored depressions would require active re-introduction. A small-plot test study showed that rooted transplants of both species could be introduced successfully (De Steven and Sharitz 2007), but effort and cost could be prohibitive on a large scale. 
Table 4 Number of wetlands (of 8 per target vegetation type) meeting metric criteria by year 5 relative to increase from pre-restoration value and to reference threshold value

\begin{tabular}{|c|c|c|c|c|c|c|c|}
\hline Target Vegetation & Hydroperiod & $\begin{array}{l}\text { Species } \\
\text { richness }\end{array}$ & $\begin{array}{l}\% \text { Herb } \\
\text { species }\end{array}$ & $\begin{array}{l}\% \text { Wetland } \\
\text { species }\end{array}$ & $\begin{array}{l}\text { Herb species } \\
\text { cover }\end{array}$ & $\begin{array}{l}\text { Wetland species } \\
\text { cover }\end{array}$ & $\begin{array}{l}\text { Both cover } \\
\text { criteria }\end{array}$ \\
\hline & \multicolumn{7}{|c|}{ Number of wetlands with net increases in metric: } \\
\hline Herbaceous & 8 & 8 & 8 & 8 & 8 & 7 & 7 \\
\hline Wet Forest & 6 & 8 & 8 & 8 & 8 & 6 & 6 \\
\hline \multirow[t]{2}{*}{ Total } & 14 & 16 & 16 & 16 & 16 & 13 & 13 \\
\hline & \multicolumn{7}{|c|}{ Number of wetlands achieving reference threshold for metric: } \\
\hline Herbaceous & 3 & 8 & 7 & 6 & 5 & 5 & 3 \\
\hline Wet Forest & 6 & 8 & 8 & 5 & 8 & 5 & 5 \\
\hline Total & 9 & 16 & 15 & 11 & 13 & 10 & 8 \\
\hline
\end{tabular}

The inability of some experimental wetlands to develop the planned target vegetation can be understood from current models of depressional-wetland dynamics. Depression vegetation type (aquatic, herbaceous, forested) is influenced by the intrinsic hydroperiod, which in turn is shaped by basin geomorphology and other factors in ways not fully understood (Kirkman et al. 2000; De Steven and Toner 2004; see also Stewart and Kantrud 1971). Community types and species composition are also linked dynamically through temporally variable hydrology that allows vegetation change. In Southeastern depressions, succession toward forest is favored by inherently short (seasonal to temporary) hydroperiods or by drought periods that permit flood-tolerant woody plants to establish. Conversely, herbaceous vegetation is maintained by inherently long (semi-permanent) hydroperiods that suppress woody seedlings, or by frequent fire if hydroperiods are short. The experiment had assigned a priori vegetation targets to wetlands whose individual hydroperiods could not be predicted. By chance, five of eight herbaceouswetland assignments had hydroperiods that inherently were too short to favor a persistent herbaceous community. Likewise, two of eight wet-forest assignments had temporary hydroperiods shorter than typical for wet forests, even though wet-forest tree species were planted successfully in all. Thus, inability to match the desired plant community reflected an incompatibility between the intended vegetation and the depression's natural hydrologic capacity to support it.

In particular, the experimental results demonstrated that forest removal and hydrology restoration alone are insufficient to maintain a herbaceous community if depressions are small and natural hydroperiods are short. Management with prescribed fire can counteract woody plant succession in such wetlands (e.g., Martin and Kirkman 2009), but this was not achieved in the experiment. In shorter-hydroperiod restored sites, woody-plant resprouting and colonization (De Steven et al. 2006) established a trajectory toward forested wetland irrespective of planting treatment. Rather than using intensive chemical control to prevent sprouting, the project plan had anticipated relying on slash-reduction burns after site harvest and rapid ponding after ditch plugging. However, unexpected drought imposed restrictions on prescribed fire and also slowed hydrologic recovery, thus favoring woody regrowth. Had the intended suppression methods been accomplished early, more sites might have achieved herbaceous-wetland traits over the short term, though perhaps not in the long term. Ultimately, preventing woody-plant succession in short-hydroperiod depressions would require frequent burning or repeated chemical applications (e.g., Moser 2009).

The generally positive outcomes of passive restoration in these Southeastern depressions reflect a particular land use history, and thus illustrate a role of regional context. Studies of Northern prairie pothole wetlands have found passive methods inadequate for restoring plant diversity (Seabloom and van der Valk 2003; Aronson and Galatowitsch 2008). That region is characterized by widespread intensive agriculture and substantial historic wetland loss, so restored potholes may be isolated from source wetlands and easily colonized by invasive plants. Missing species guilds appear difficult to reintroduce (Budelsky and Galatowitsch 2000). In contrast, despite several centuries of post-settlement land uses (Martin and Boyce 1993; Otto 1994), the Southeast region remains a diverse mix of forests, agriculture, and interspersed wetlands. The SRS depressions were in a naturalized forest setting and not highly degraded, having "self-restored" to some extent after abandonment. Diverse wetland seed banks had persisted or redeveloped, and invasive species were insignificant. The missing clonal-dominant guild appeared relatively easy to establish (De Steven and Sharitz 2007). Passive revegetation of Southeastern depressions might be less successful on agricultural lands, where drained depressions could have 
depleted seed banks and greater adjacent disturbance. This question cannot yet be resolved because wetland restoration in Southeastern agricultural settings is largely unstudied (De Steven and Lowrance 2010),

\section{Passive Restoration and Mitigation-Bank Success}

Evaluating ecological restoration success is uniquely challenging for wetlands because of the high stakes involved in regulating and mitigating wetland losses (Zedler 2000). Problems with compensatory mitigation have been reviewed extensively (NRC 2001); frequent failures are attributed to causes such as unsuitable project sites, use of wetland creation rather than restoration, unscientific performance standards, or poorly defined goals. In a single-permit compensatory mitigation, failure to achieve equivalence to natural wetlands is of concern because the mitigation site is replacing a particular lost wetland type either concurrently or "after the fact". A potential advantage of mitigation banks is that if they hold a collection of restored wetlands with good ecological function (hydrology, vegetation, faunal habitat), the regulatory issue shifts to determining if an appropriate wetland type is available "before the fact" for in-kind replacement (Spieles 2005). Regardless of this advantage, the challenge remains that restoration success is rarely a simple yes/no outcome (Zedler and Callaway 2000). Assessment periods are typically shorter than the time needed for restored systems to mature. The desired standard of resemblance to natural wetlands does not indicate what traits best reflect that resemblance, nor what degree of resemblance is "similar enough", given that even reference wetlands are variable.

Evaluating the SRS experimental restorations in the context of mitigation-bank crediting illustrated some of these complexities. The project was a "best-practices" scenario where depressions were restored in place (not created), performance criteria were scientifically based, and conditions favored passive revegetation (i.e., benign land-use setting, suitable geomorphic location and soils, restorable hydrology, native wetland seed banks). All wetlands recovered their intrinsic hydrologic functions and developed diverse native plant communities. Thirteen wetlands met the net-improvement goals of increased hydroperiod and wetland plant composition; three wetlands were enhanced but showed fewer net changes, suggesting that drainage was already ineffective without ditch plugging. Although young in successional age, the restored wetlands were comparable in hydroperiods and vegetation traits to a spectrum of natural herbaceous and forested communities that are related to each other dynamically. The dispersal-limited clonal dominants (maidencane, southern cutgrass) were re-introduced on a small scale by the test study (De Steven and Sharitz 2007).
The restored sites were also documented as supporting habitat use by bats, aquatic invertebrates, waterbirds, and pond-breeding amphibians (Menzel et al. 2005; Taylor and DeBiase 2005; Barton et al. 2007). Thus, these functional wetlands would meet or exceed the ecological performance standards advocated for mitigation-bank success (e.g., Spieles 2005; Reiss et al. 2009).

However, with fixed vegetation targets assigned to individual depressions, assessment in relation to reference produced a paradoxical result. Because assigned targets were often incompatible with system capacity, up to half of these ecologically successful wetlands might be considered "failures" for mitigation-bank crediting because they did not (and could not) achieve all the attributes of the chosen target. This result was less a failure of restoration than a failure to recognize site-based ecological constraints on achieving specific vegetation goals. On their present trajectories, the wetlands will provide viable hydrologic, habitat, and biodiversity functions, regardless of the original goal. As the project was not a compensatory mitigation, there was no fixed requirement for certain acreages of herbaceous or forested depression to be entered into the mitigation bank (US-DOE 1997); instead, the collection of wetlands would be available to mitigate for future loss of herbaceous or forested wetlands, as appropriate.

Given the dynamic nature of depression vegetation (Kirkman et al. 2000; De Steven and Toner 2004), specifying a particular plant community for a restored site is problematic when hydrology cannot be predicted. Unpredictable drought effects are not easily remediated once sites have established a vegetation trajectory. Future vegetation in each restored site will be contingent on inherent hydroperiod, new species colonizations, legacies of tree resprouting, and the type of adjacent upland forest management. Thus, more flexible restoration targets based on a spectrum of natural communities could be warranted (cf. Thom 2000). This approach is consistent with adaptive management concepts, which include re-evaluating the ecological feasibility of restoration goals in light of unexpected outcomes (Kentula 2000; Thom 2000).

Discussions concerning appropriate restoration goals and reference conditions are ongoing (Stoddard et al. 2006; Choi 2007). Reference wetlands serve as important benchmarks, but there is some risk of a typological view that under-appreciates the multiple possible states and dynamic variability of natural wetlands (Pickett and Parker 1994; Suding et al. 2004). Measuring success by plant floristic similarity alone may overlook other traits more indicative of wetland functions (NRC 2001). Restoration context, feasibility of intensive management, and future sustainability of natural processes are important considerations in setting goals and choosing the restoration approach (Ehrenfeld 2000). For depressional wetlands, diagnostics that consider current 
condition, adequacy of seed banks, adjacent land uses, and process-based vegetation dynamics could identify where passive restoration can produce successful ecological outcomes versus where more active interventions (e.g., introducing key plant taxa or controlling invasives) may be needed.

Acknowledgments We sincerely thank John Blake, U.S. Forest Service-Savannah River, for sustained dedication to overall project management, and also Randy Kolka and Don Imm for their early contributions. For field assistance, we especially thank J. Singer, J. Mulhouse, L. Lee, P. Stankus, A. Harrison, and A. Lowrance. T. Dell and R. Souter advised on statistics. Comments by B. Collins, R. Kolka, and several reviewers and editors greatly improved the manuscript. Funding was provided by the DOE-Savannah River Operations Office (Agreements DE-IA09-76SR00056 and DE-IA0900SR22188 with the USFS-Savannah River), the DOE Office of Biological and Environmental Research (Award DE-FC0996SR18546 to The Univ. of Georgia Research Foundation), and by Cooperative Agreements with the USFS-Savannah River (01-CA11083600-011, 03-CS-11083600-002) and the Center for Forested Wetlands Research (01-CA-11330135-457).

\section{References}

ACOE [Army Corps of Engineers] Environmental Laboratory (1987) Wetlands delineation manual. U.S. Army Engineer Waterways Experiment Station, Vicksburg, Mississippi

Aronson MFJ, Galatowitsch SM (2008) Long-term vegetation development of restored prairie pothole wetlands. Wetlands 28:883-895

Barton CD, Singer J (2001) The Carolina bay restoration project: SRS wetland mitigation bank document. DOE Paper ESH-ESS-200200028, Westinghouse Savannah River Co., Aiken, South Carolina

Barton CD, De Steven D, Kilgo JC (2004) Mitigation bank promotes research on restoring coastal plain depression wetlands. Ecological Restoration 22:291-292

Barton CD, De Steven D, Sharitz R, Kilgo J, Kinkead K, Otis D, Hanlin H, Ledvina J, Taylor B, Blake J (2007) The Carolina bay restoration project: final report 2000-2006. Technical Report DEA109-00SR22188, U.S. Department of Energy, Washington, DC

Barton CD, Andrews DM, Kolka RK (2008) Evaluating hydroperiod response in restored Carolina bay wetlands using soil physicochemical properties. Restoration Ecology 16:668-677 (and corrigendum 17:441)

Budelsky RA, Galatowitsch SM (2000) Effects of water regime and competition on the establishment of a native sedge in restored wetlands. Journal of Applied Ecology 37:971-985

Casey WP, Ewel KC (2006) Patterns of succession in forested depressional wetlands in North Florida, USA. Wetlands 26:147-160

Choi YD (2007) Restoration ecology to the future: a call for new paradigm. Restoration Ecology 15:351-353

De Steven D, Lowrance R, (2011). Agricultural conservation practices and wetland ecosystem services in a wetland-rich landscape: the Piedmont-Coastal Plain region. Ecological Applications (Supplement)

De Steven D, Sharitz RR (2007) Transplanting native dominant plants to facilitate community development in restored Coastal Plain wetlands. Wetlands 27:972-978

De Steven D, Toner MM (2004) Vegetation of Upper Coastal Plain depression wetlands: environmental templates and wetland dynamics within a landscape framework. Wetlands 24:23-42
De Steven D, Sharitz RR, Singer JH, Barton CD (2006) Testing a passive revegetation approach for restoring Coastal Plain depression wetlands. Restoration Ecology 14:452-460

Ehrenfeld JG (2000) Defining the limits of restoration: the need for realistic goals. Restoration Ecology 8:2-9

Galatowitsch SM, van der Valk AG (1996a) Characteristics of recently restored wetlands in the prairie pothole region. Wetlands 16:7583

Galatowitsch SM, van der Valk AG (1996b) The vegetation of restored and natural prairie wetlands. Ecological Applications 6:102-112

Godfrey RK, Wooten JW (1981) Aquatic and wetland plants of the southeastern United States. University of Georgia Press, Athens

Halle S (2007) Science, art, or application - the "karma" of restoration ecology. Restoration Ecology 15:358-361

Hobbs RJ (2007) Setting effective and realistic restoration goals: key directions for research. Restoration Ecology 15:354-357

Jongman RHG, ter Braak CJF, van Tongeren LFR (1995) Data analysis in community and landscape ecology. Cambridge University Press, Cambridge

Kentula ME (2000) Perspectives on setting success criteria for wetland restoration. Ecological Engineering 15:199-209

Kilgo JC, Blake JI (2005) Ecology and management of a forested landscape: fifty years on the Savannah River Site. Island, Washington

Kirkman LK (1995) Impacts of fire and hydrological regimes on vegetation in depression wetlands of southeastern USA. In: Cerulean SI, Engstrom RT (eds) Fire in wetlands: a management perspective. Tall Timbers, Tallahassee, pp 10-20

Kirkman LK, Lide RF, Wein G, Sharitz RR (1996) Vegetation changes and land-use legacies of depression wetlands of the western coastal plain of South Carolina: 1951-1992. Wetlands 16:564576

Kirkman LK, Goebel PC, West L, Drew MB, Palik BJ (2000) Depressional wetland vegetation types: a question of plant community development. Wetlands 20:373-385

Kolka RK, Nelson EA, Trettin CC (2000) Conceptual assessment framework for forested wetland restoration. Ecological Engineering 15:S17-S21

Martin WH, Boyce SG (1993) The Southeastern setting. In: Martin WH, Boyce SG, Echternacht AC (eds) Biodiversity of the southeastern United States. Wiley, New York, pp 1-46

Martin KL, Kirkman LK (2009) Management of ecological thresholds to re-establish disturbance-maintained herbaceous wetlands of the southeastern USA. Journal of Applied Ecology 46:906914

Matthews JW, Endress AG (2008) Performance criteria, compliance success, and vegetation development in compensatory mitigation wetlands. Environmental Management 41:130-141

McCune B, Grace JB (2002) Analysis of ecological communities. MjM Software Design, Gleneden Beach

Menzel MA, Menzel JM, Kilgo JC, Ford WM, Edwards JW (2005) Bat response to Carolina bays and wetland restoration in the southeastern U.S. Coastal Plain. Wetlands 25:542-550

Mitsch WJ, Wilson RF (1996) Improving the success of wetland creation and restoration with know-how, time, and self-design. Ecological Applications 6:77-83

Mitsch WJ, Wu X, Nairn RW, Weihe PE, Wang N, Deal R, Boucher CE (1998) Creating and restoring wetlands. Bioscience 48:10191030

Moser LJ (2009) The effects of hardwood re-sprout control in hydrologically restored Carolina bay depression wetlands. Master's thesis. University of Kentucky, Lexington

Mulhouse JM, Galatowitsch SM (2003) Revegetation of prairie pothole wetlands in the mid-continental US: twelve years postreflooding. Plant Ecology 169:143-159 
Mulhouse JM, De Steven D, Lide RF, Sharitz RR (2005) Effects of dominant species on vegetation change in Carolina bay wetlands during a multi-year drought. Journal of Torrey Botanical Society 132:411-420

NRC [National Research Council] (2001) Compensating for wetland losses under the Clean Water Act. National Academy Press, Washington

Osteen DV (2003) Revised success criteria and credit release schedule for Carolina bay restoration plan. Letter of November 6, 2003, to U.S. Army Corps of Engineers. Westinghouse Savannah River Company, Aiken, South Carolina.

Otto JS (1994) Southern agriculture during the Civil War Era, 18601880. Greenwood, Westport

Peet RK, Wentworth TR, White PS (1998) A flexible, multipurpose method for recording vegetation composition and structure. Castanea 63:262-274

Pickett STA, Parker VT (1994) Avoiding the old pitfalls: opportunity in a new discipline. Restoration Ecology 2:75-79

Reed PB Jr (1997) Revision of the national list of plant species that occur in wetlands. U.S Fish and Wildlife Service, Washington

Reiss KC, Hernandez E, Brown MT (2009) Evaluation of permit success in wetland mitigation banking: a Florida case study. Wetlands 29:907-918

Seabloom EW, van der Valk AG (2003) Plant diversity, composition, and invasion of restored and natural prairie pothole wetlands: implications for restoration. Wetlands 23:1-12

Sharitz RR, Barton CD, De Steven D (2006) Tree plantings in depression wetland restorations show mixed success. Ecological Restoration 24:114-115

Singer JH (2001) Effect of overstory removal and fire on wetland vegetation and recruitment from the seed bank in a hydrologically restored Carolina bay wetland. Master's thesis. University of Georgia, Athens

Spieles DJ (2005) Vegetation development in created, restored, and enhanced mitigation wetland banks of the United States. Wetlands 25:51-63
Stewart RE, Kantrud HA (1971) Classification of natural ponds and lakes in the glaciated prairie region. Resource Publ. 92, U.S. Fish and Wildlife Service, Washington, DC

Stoddard JL, Larsen DP, Hawkins CP, Johnson RK, Norris RH (2006) Setting expectations for the ecological condition of streams: the concept of reference condition. Ecological Applications 16:12671276

Stroh CL, De Steven D, Guntenspergen GR (2008) Effect of climate fluctuation on long-term vegetation dynamics in Carolina bay wetlands. Wetlands 28:17-27

Suding KN, Gross KL, Houseman GR (2004) Alternative states and positive feedbacks in restoration ecology. Trends in Ecology \& Evolution 19:46-53

Szuch RP, White JG, Vepraskas MJ, Doolittle JA (2006) Application of ground penetrating radar to aid restoration planning for a drained Carolina bay. Wetlands 26:205-216

Taylor BE, DeBiase AE (2005) Are microcrustaceans useful for assessing success of wetland pond restoration? Ecological Restoration 23:56-57

Thom RM (2000) Adaptive management of coastal restoration projects. Ecological Engineering 15:365-372

Underwood AJ (1994) On beyond BACI: sampling designs that might reliably detect environmental disturbances. Ecological Applications $4: 3-15$

US-DOE [Department of Energy] (1997) Memorandum of agreement for the Savannah River Site wetland mitigation bank. DOE Document DE-MA09-96SR18577, SRS Operations, New Ellenton, South Carolina

van der Valk AG (1981) Succession in wetlands: a Gleasonian approach. Ecology 62:688-696

White PS, Walker JL (1997) Approximating nature's variation: selecting and using reference information in restoration ecology. Restoration Ecology 5:338-349

Zedler JB (2000) Progress in wetland restoration ecology. Trends in Ecology \& Evolution 15:402-407

Zedler JB, Callaway JC (2000) Evaluating the progress of engineered tidal wetlands. Ecological Engineering 15:211-225 